STUDIA I PRACE WYDZIAŁU NAUK EKONOMICZNYCH I ZARZĄDZANIA NR 40, T. 2

DOI: $10.18276 /$ sip.2015.40/2-19

Barbara Kryk $^{*}$

Uniwersytet Szczeciński

\title{
ŚRODOWISKOWE UWARUNKOWANIA JAKOŚCI ŻYCIA W POWIATACH WOJEWÓDZTWA ZACHODNIOPOMORSKIEGO
}

\section{STRESZCZENIE}

Od pewnego czasu istotnym czynnikiem oddziałującym na jakość życia jest stan środowiska naturalnego, dlatego w niniejszym artykule postanowiono przeanalizować to zagadnienie. Przedstawiono wyniki pomiaru obiektywnej jakości życia w tym obszarze w powiatach województwa zachodniopomorskiego oraz wskazano mocne i słabe strony dotyczące uwarunkowań środowiskowych. W opracowaniu wykorzystano metody desk research oraz analizy taksonomicznej.

Słowa kluczowe: jakość życia, region, uwarunkowania środowiskowe

\section{Wprowadzenie}

Problematyka ochrony środowiska naturalnego jest jednym z najważniejszych wyzwań naszych czasów, które w mniejszym lub większym stopniu dotyczy wszystkich ludzi. Stan środowiska naturalnego determinuje jakość życia i trwałość rozwoju, dlatego istotną rolę odgrywa racjonalne gospodarowanie jego zasobami. Osłabianie lub degradowanie struktury zasobów naturalnych powoduje ich bezpowrotne zniszczenie, wskutek czego kapitał ekologiczny zostaje pozbawiony swoich podstawowych funkcji, co z kolei z powodu naruszenia równowagi w ekosystemach uniemożliwia kontynuację

\footnotetext{
*Adres e-mail: krykb@wneiz.pl.
} 
zrównoważonego rozwoju i negatywnie wpływa na jakość życia. Należy więc m.in. monitorować działania proochronne, aby nie dopuścić do pogorszenia jakości życia. Biorąc powyższe pod uwagę, przyjęto jako cel artykułu ocenę poziomu obiektywnej jakości życia w obszarze uwarunkowań środowiskowych w powiatach województwa zachodniopomorskiego oraz wskazanie mocnych i słabych strony w tym zakresie.

W artykule wykorzystano część wyników badań przeprowadzonych na potrzeby raportu wykonanego na zlecenie Wydziału Zarządzania Strategicznego Urzędu Marszałkowskiego Województwa Zachodniopomorskiego pt. „Czynniki podnoszenia jakości życia i dostępności do usług publicznych na obszarze województwa zachodniopomorskiego". W jego przygotowaniu aktywnie uczestniczyła autorka opracowania jako ekspert ds. jakości życia i zrównoważonego rozwoju. Raport był przygotowany w okresie od kwietnia do lipca 2014 roku.

\section{Metodologia badań ${ }^{1}$}

Jak wiadomo, ocenę obiektywnej jakości życia można przeprowadzić, biorąc pod uwagę trzy dziedzinowe jakości życia - społeczną, ekonomiczną i środowisko$w_{a}{ }^{2}$. To podejście zastosowano $\mathrm{w}$ niniejszym opracowaniu do oceny jakości życia mieszkańców województwa zachodniopomorskiego w obszarze uwarunkowań środowiskowych. W procesie oceny wykorzystano analizę taksonomiczną. W związku z tym przyjęto obowiązujący $\mathrm{w}$ jej przypadku schemat postępowania, obejmujący następujące etapy analizy zróżnicowania obiektów wielocechowych: 1) określenie podmiotu badań, 2) jakościowa weryfikacja cech, 3) korelacyjna weryfikacja cech, 4) ustalenie zestawu cech diagnostycznych, 5) normalizacja cech, 6) budowa mierników agregatowych, 7) grupowanie obiektów pod względem podobieństwa, 8) sprawdzenie jakości uzyskanego grupowania.

Podmiotem badań były powiaty województwa zachodniopomorskiego, a przedmiotem obiektywna jakość życia w zakresie uwarunkowań środowiskowych.

${ }^{1}$ Ze względu na ograniczony zakres opracowania opis metodologii jest bardzo syntetyczny, gdyż uznano, że ważniejsze jest zaprezentowanie wyników badań niż szczegółowe omawianie standardowej metody badań. G. Karmowska, M. Krawczyk, B. Kryk, G. Maniak, M. Marciniak, Czynniki podnoszenia jakości życia i dostępności do ustug publicznych na obszarze województwa zachodniopomorskiego, Raport dla Urzędu Marszałkowskiego WZP, Szczecin 2014.

${ }^{2}$ Zob. T. Borys, Jakość życia jako integrujący rodzaj jakości, w: Jakość życia w perspektywie nauk humanistycznych, ekonomicznych i ekologii, Akademia Ekonomiczna we Wrocławiu, Jelenia Góra 2003, s. 9-20. 
Ocena zróżnicowania między powiatami jest pochodną obszarów rozwoju regionalnego, dlatego wykorzystano miary statystyczne informujące o stopniu zróżnicowania regionalnego: obszar zmienności cechy, wartość maksymalna, wartość minimalna, odchylenie standardowe, współczynnik zmienności. Wartości tych miar informują o stopniu zróżnicowania poziomu rozwoju między badanymi obiektami przestrzennymi ${ }^{3}$. Do wstępnej analizy zróżnicowania poszczególnych zmiennych diagnostycznych przyjęto przyrosty bezwzględne, wskazujące różnicę między wartościami zmiennej w latach 2012 i $2007^{4}$, oraz przyrosty względne (stosunek wartości), gdzie za okres bazowy przyjęto rok 2007. Do oceny jakości życia w zakresie infrastruktury socjalnej i pomocy społecznej oraz bezpieczeństwa publicznego wykorzystano wielopłaszczyznową analizę porównawczą, która umożliwiła sporządzenie liniowego rankingu województw pod względem badanej cechy, a także metodę podziału badanych obiektów na cztery klasy (grupy). Zaklasyfikowanie powiatu do danej grupy odpowiada ocenie jego poziomu obiektywnej jakości życia.

W niniejszym opracowaniu do oceny uwarunkowań środowiskowych jakości życia wykorzystano - jak już wspomniano - tylko dostępne w danym momencie wskaźniki. Na poziomie powiatów były to następujące zmienne:

- udział obszarów prawnie chronionych w powierzchni ogółem [\%] $]^{5}$ (stymulanta $)^{6}$

- odpady wytwarzane w ciągu roku na $1 \mathrm{~km}^{2} \mathrm{w}$ powiatach $[t]$ (destymulanta),

${ }^{3}$ Por. K. Kukuła, Elementy statystyki w zadaniach, Wydawnictwo Naukowe PWN, Warszawa 2010; Z. Hellwig, Taksonometria ekonomiczna, jej osiagnięcia, zadania i cele, w: Taksonomia - teoria i jej zastosowania, Akademia Ekonomiczna w Krakowie, Kraków 1990; K. Jajuga, M. Walesiak, Taxonomic Conferences - Some Facts and Remarks, w: Taksonomia 14. Klasyfikacja i analiza danych - teoria $i$ zastosowania, Prace Naukowe Akademii Ekonomicznej im. Oskara Langego we Wrocławiu, Wrocław 2007; Taksonomiczna analiza przestrzennego zróżnicowania poziomu życia w Polsce $w$ ujęciu dynamicznym, red. A. Zeliaś, Wydawnictwo Akademii Ekonomicznej w Krakowie, Kraków 2000.

${ }^{4}$ W czasie pisania opracowania były dostępne dane tylko za okres 2007-2012.

${ }^{5}$ Na poziomie NUTS 4 ta zmienna miała większą wartość informacyjną niż powierzchnia obszarów chronionych, dlatego ją przyjęto do obliczeń.

${ }^{6}$ Może się to wydawać kontrowersyjne, ale na to po pierwsze wskazuje statystyczny charakter zmiennej, po drugie nie zawsze istnieje negatywny związek między ilością obszarów prawnie chronionych a poziomem gospodarczym powiatu (przykładem są chociażby powiat gryfiński i m. Świnoujście o relatywnie dużych powierzchniach obszarów prawnie chronionych, dużych ilościach zanieczyszczeń i wyższym poziomie rozwoju ze względu na funkcjonujące tam duże przedsiębiorstwa, czy powiat kołobrzeski korzystający właśnie z tego, że ma dobre warunki środowiskowe, dzięki którym jest największym nadmorskim uzdrowiskiem w kraju). 
- emisja zanieczyszczeń pyłowych w tonach/rok/100 km²(destymulanta),

- emisja zanieczyszczeń gazowych w tonach/rok/100 km² (destymulanta).

Ze względu na ograniczoność danych do badania analizę rankingu powiatów i grupowanie ich na klasy uzupełniono analizą porównawczą kształtowania się wyżej wymienionych wskaźników w badanym okresie.

\section{Zróżnicowanie jakości życia mieszkańców w badanym zakresie w powiatach województwa zachodniopomorskiego}

Województwo zachodniopomorskie, położone w północno-zachodniej części Polski, jest jednym z największych województw i zajmuje powierzchnię $22892,48 \mathrm{~km}^{2}$. Jest podzielone na 21 powiatów, z czego trzy z nich to powiaty grodzkie, tj. miasta na prawach powiatu: Koszalin, Szczecin i Świnoujście.

Na podstawie zestandaryzowanych zmiennych sporządzono ranking powiatów w województwie zachodniopomorskim dla obszaru uwarunkowań środowiskowych (tabela 1). W rankingu nie można było przypisać miejsca dwóm powiatom (kamieńskiemu i pyrzyckiemu) ze względu na brak danych o nich w Banku Danych Lokalnych.

Analizując ranking przedstawiony w tabeli 1, można zauważyć, że w 2007 roku trzema najlepszymi pod względem warunków środowiskowych powiatami były powiaty: gryficki, świdwiński i drawski. Powiat gryficki wytwarzał ponad 90 razy mniej odpadów w ciągu roku na $1 \mathrm{~km}^{2}$ niż wynosiła średnia wartość tego wskaźnika dla województwa zachodniopomorskiego oraz emitował 12 razy mniej pyłów [w tonach/ rok/100 km²] i 52 razy mniej gazów [w tonach/rok/100 km²]. Powiat świdwiński wytwarzał jeszcze mniej odpadów (około 187 razy) niż wynosiła średnia wojewódzka, również emitował 12 razy mniej pyłów [w tonach/rok/100 $\mathrm{k} \mathrm{m}^{2}$ ] i prawie 38 razy mniej gazów [w tonach/rok/100 km²] w porównaniu do średniej dla województwa. Powiat drawski również miał bardzo niskie wskaźniki zanieczyszczeń - wytwarzał prawie 298 razy mniej odpadów w ciągu roku na $1 \mathrm{~km}^{2}$, emitował 6 razy mniej zanieczyszczeń pyłowych i 52 razy mniej zanieczyszczeń gazowych [w tonach/rok $/ 100 \mathrm{~km}^{2}$ ] w porównaniu do średnich wartości tych wskaźników dla województwa. Ponadto powiat drawski miał jeden z najwyższych wskaźników udziału obszarów prawnie chronionych w powierzchni ogółem (rysunki 1-4). Synergia tych niskich wskaźników zdeterminowała wysoką pozycję omawianych powiatów w województwie pod względem uwarunkowań środowiskowych. Mniejsze obciążenie środowiska przy- 
rodniczego w tych (i kilkunastu innych) powiatach jest związane z charakterem i skalą istniejących tam przedsiębiorstw. $Z$ reguły nie funkcjonują tam duże zakłady przemysłowe, wytwarzające zanieczyszczenia. Poza tym po upadku PGR-ów polikwidowano również tzw. przedsiębiorstwa okołorolnicze i przetwórstwa spożywczego, co miało pozytywny wpływ na stan środowiska przyrodniczego, ale negatywny na rynek pracy i poziom gospodarczy. Stąd tak ważne jest przyspieszenie prac związanych m.in. z promowaniem walorów turystycznych województwa zachodniopomorskiego.

Tabela 1. Ranking powiatów według zmiennych opisujących uwarunkowania środowiskowe

\begin{tabular}{|c|l|c|c|}
\hline Lp. & \multicolumn{1}{|c|}{ Powiat } & Miejsce w 2007 r. & Miejsce w 2012 r. \\
\hline 1. & kamieński & b.d & b.d \\
\hline 2. & pyrzycki & b.d. & b.d. \\
\hline 3. & gryficki & 1. & 8. \\
\hline 4. & świdwiński & 2. & 4. \\
\hline 5. & drawski & 3. & 7. \\
\hline 6. & sławieński & 4. & 1. \\
\hline 7. & choszczeński & 5. & 2. \\
\hline 8. & wałecki & 6. & 12. \\
\hline 9. & łobeski & 7. & 5. \\
\hline 10. & koszaliński & 8. & 11. \\
\hline 11. & goleniowski & 9. & 14. \\
\hline 12. & białogardzki & 10. & 3. \\
\hline 13. & myśliborski & 11. & 10. \\
\hline 14. & kołobrzeski & 12. & 9. \\
\hline 15. & stargardzki & 13. & 6. \\
\hline 16. & szczecinecki & 14. & 17. \\
\hline 17. & m. Świnoujście & 15. & 16. \\
\hline 18. & m. Koszalin & 16. & 15. \\
\hline 19. & gryfiński & 17. & 19. \\
\hline 20. & policki & 18. & 19. \\
\hline 21. & m. Szczecin & & \\
\hline & & 19. & \\
\hline
\end{tabular}

Źródło: opracowanie własne na podstawie badań.

W 2007 roku trzy ostatnie miejsca w rankingu zajmowały powiaty: gryfiński, policki i m. Szczecin, w których analizowane wskaźniki obciążeń środowiska były najwyższe w województwie ze względu na umiejscowienie w nich dużych środowiskowo 
uciążliwych przedsiębiorstw oraz skumulowanie relatywnie dużej liczby różnych podmiotów gospodarczych. Powiat gryfiński wytwarzał 1,3 razy więcej odpadów w ciągu roku na $1 \mathrm{~km}^{2}$, emitował 2,7 razy więcej pyłów i 7,4 razy więcej gazów [w tonach/ rok/100 km²] w porównaniu do średnich wartości tych wskaźników dla województwa. Powiat policki wytwarzał 23 razy więcej odpadów w ciągu roku na $1 \mathrm{~km}^{2}$, emitował 4,8 razy więcej pyłów i 5,3 razy więcej gazów [w tonach/rok/100 $\mathrm{km}^{2}$ ] niż wynosiła średnia wojewódzka. Miasto Szczecin wytwarzało 2,7 razy więcej odpadów w ciągu roku na $1 \mathrm{~km}^{2}$, emitowało 12,7 razy więcej pyłów i 9,4 razy więcej gazów [w tonach/ rok/100 km²] w porównaniu do średnich wartości tych wskaźników dla województwa. W dwóch ostatnich powiatach dodatkowo był niski wskaźnik udziału obszarów prawnie chronionych w powierzchni ogółem (rysunki 1-4). Kumulacja obciążeń środowiskowych zdeterminowała pozycję omawianych powiatów w województwie.

W ciągu pięciu lat sytuacja uległa zmianie - dziewięć powiatów (około 47\% badanych) zajęło wyższe miejsca w rankingu, a dziesięć (około 52\% badanych) niższe. W 2012 roku - dzięki poczynionym inwestycjom służącym ochronie środowiska - pierwsze trzy miejsca należały do powiatów (kolejno): choszczeńskiego, wałeckiego i myśliborskiego. Awans powiatu choszczeńskiego z miejsca 5. na 1. wynikał z ograniczenia emisji zanieczyszczeń pyłowych [w tonach/rok $/ 100 \mathrm{~km}^{2}$ ] o 75\% (emisja pyłów w powiecie była 11 razy niższa od średniej wartości wskaźnika w województwie) i emisji zanieczyszczeń gazowych około 15\% (emisja gazów była 51 razy niższa w porównaniu do średniej wartości wskaźnika w województwie). Powiat wałecki awansował z miejsca 6. na 2. dzięki ograniczeniu ilości odpadów wytwarzanych w ciągu roku na $1 \mathrm{~km}^{2}$ prawie o 9\% (ilość odpadów wytwarzanych w powiecie wałeckim była około 47 razy mniejsza od średniej dla województwa) i zmniejszeniu emisji zanieczyszczeń pyłowych o około 33\% (ten wskaźnik był 3 razy niższy od średniej wartości wskaźnika dla województwa).

Największego „skoku” w rankingu - o 8 miejsc w górę (z pozycji 11. na 3.) dokonał powiat myśliborski, w którym ilość odpadów wytwarzanych w ciągu roku na $1 \mathrm{~km}^{2}$ zmniejszyła się o około 9\% (i była niższa o 1,3 razy w porównaniu do wskaźnika dla województwa), a emisja zanieczyszczeń pyłowych została ograniczona o około 67\% (emisja pyłów była 6-krotnie niższa od średniej wartości wskaźnika w województwie).

Największy spadek w rankingu (o 12 miejsc, z pozycji 1. na 13.) dotyczył powiatu gryfickiego, w którym prawie trzykrotnie wzrosła ilość wytwarzanych od- 
padów w ciągu roku na $1 \mathrm{~km}^{2}$, a ilość emitowanych zanieczyszczeń pyłowych nie uległa zmianie. To zdeterminowało pogorszenie sytuacji powiatu.

Ostatnie miejsca w rankingu zajmowały powiaty: $\mathrm{m}$. Świnoujście, $\mathrm{m}$. Szczecin, policki. Przy czym m. Świnoujście „spadło” z pozycji 15. na 17., a powiat policki z 18. na 19. Jego miejsce zajęło m. Szczecin. Przesunięcie się m. Szczecina o jedno miejsce w górę było związane z ograniczeniem ilości odpadów wytwarzanych w ciągu roku na $1 \mathrm{~km}^{2}$ o ponad $13 \%$ oraz emisji zanieczyszczeń pyłowych o ponad $65 \%$ (ich emisja była trzykrotnie niższa).

Zmiany w rankingu powiatów znalazły również odzwierciedlenie $\mathrm{w}$ ich podziale na klasy z punktu widzenia oceny poziomu uwarunkowań środowiskowych (tabela 2).

Rysunek 1. Udział obszarów prawnie chronionych w powierzchni ogółem [\%]

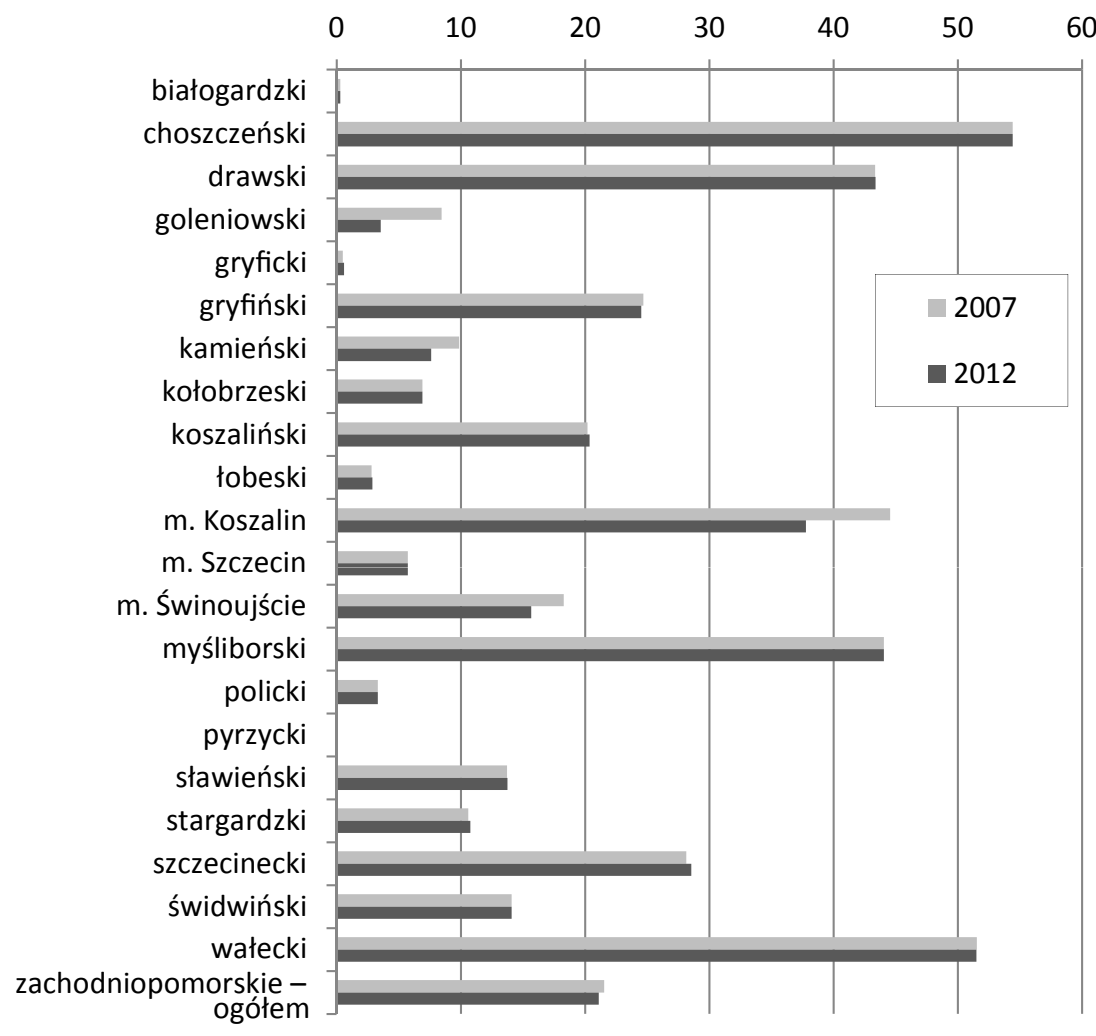

Źródło: opracowanie własne na podstawie danych z Banku Danych Lokalnych, GUS. 
Rysunek 2. Odpady wytwarzane w ciągu roku na $1 \mathrm{~km}^{2} \mathrm{w}$ powiatach $[t]$

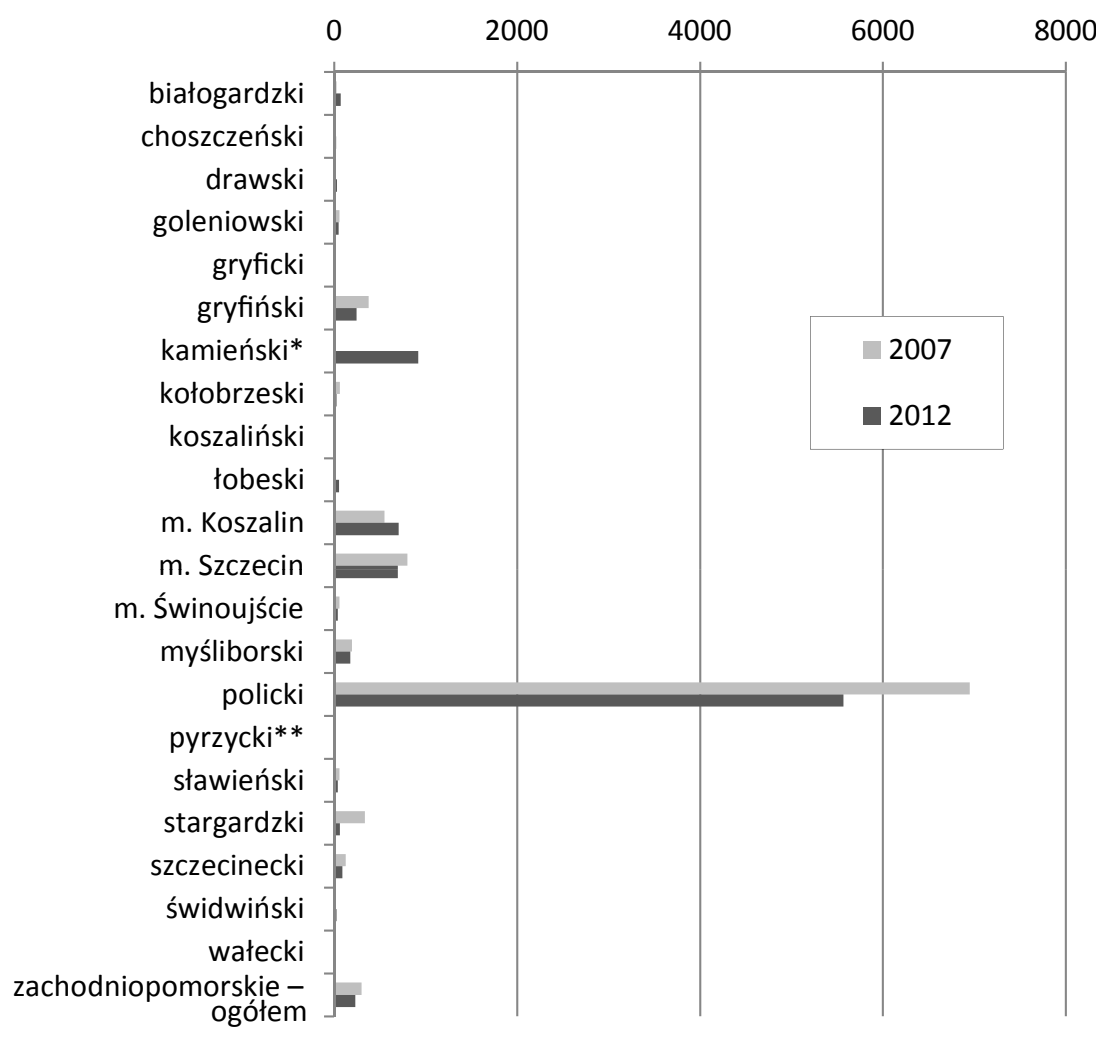

*Brak danych dla powiatu za lata 2007 i 2012, na wykresie uwzględniono dane za rok 2011.

** Brak danych dla powiatu za rok 2012

Źródło: jak pod rysunkiem 1. 
Rysunek 3. Emisja zanieczyszczeń pyłowych w tonach/rok/100 km²

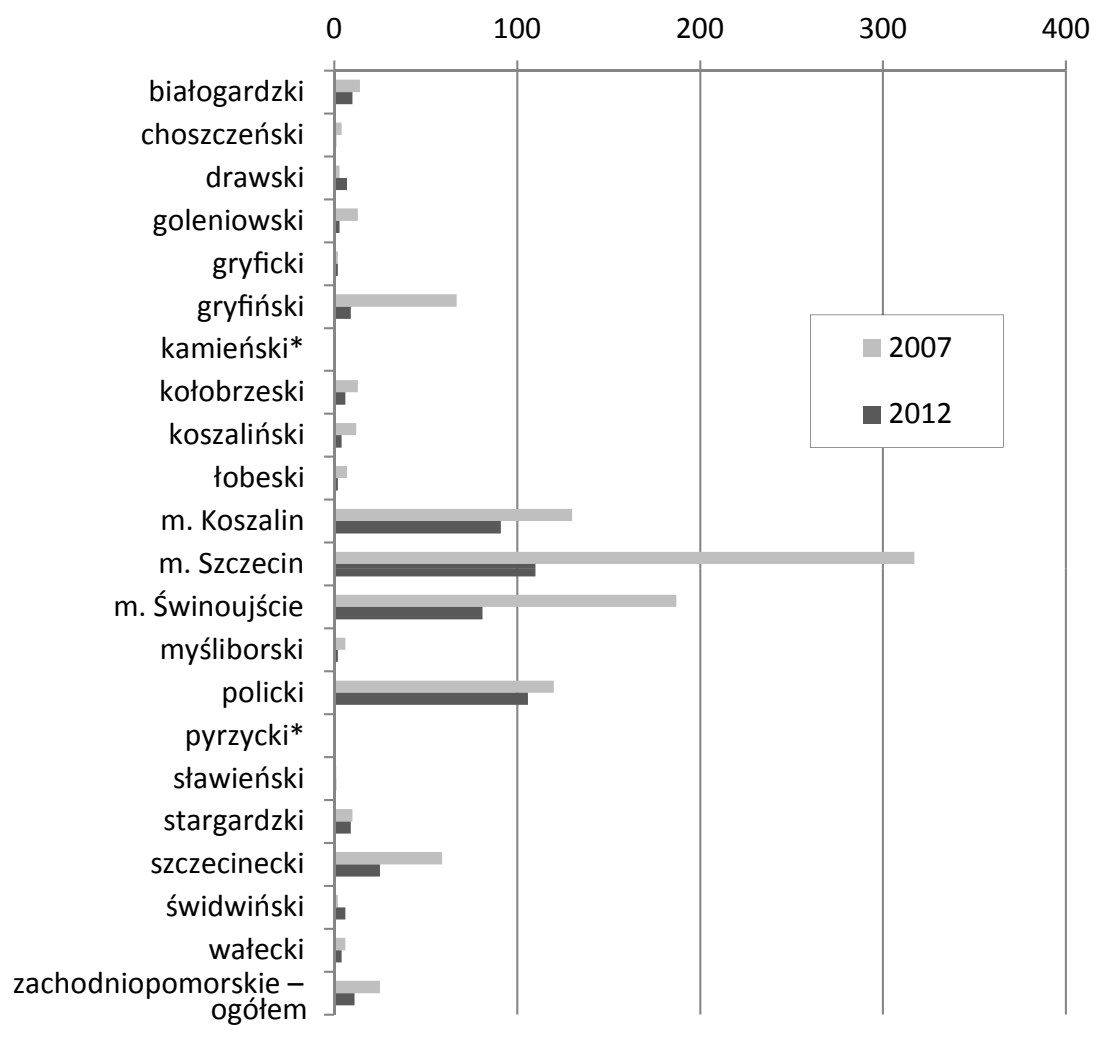

*Brak danych dla powiatu za lata 2007 i 2012.

Źródło: jak pod rysunkiem 1. 
Rysunek 4. Emisja zanieczyszczeń gazowych w tonach/rok/100 km²

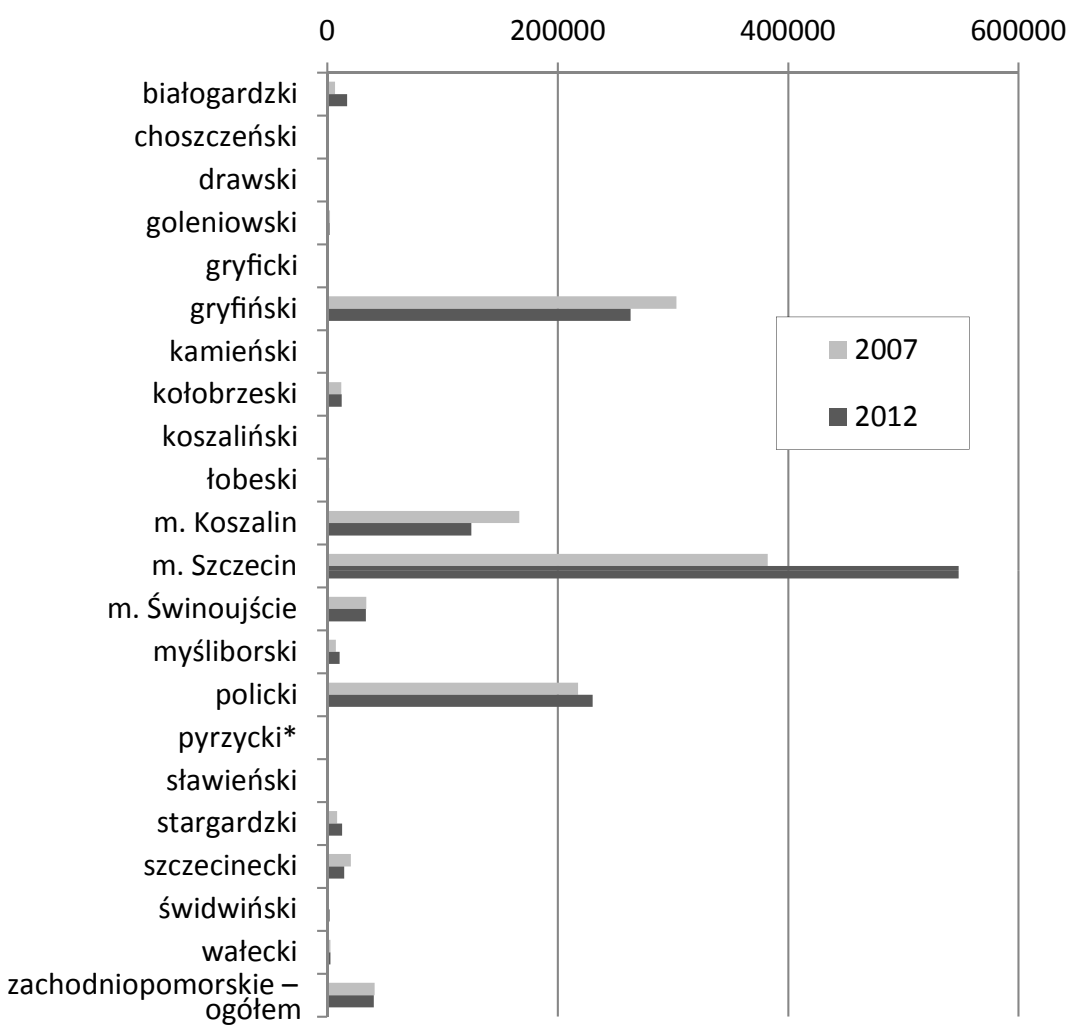

*Brak danych dla powiatu za rok 2007 i 2012. Źródło: jak pod rysunkiem 1. 
Tabela 2. Klasyfikacja powiatów według wskaźnika syntetycznego dla obszaru środowiskowego

\begin{tabular}{|c|c|c|}
\hline Klasa & 2007 rok & 2012 rok \\
\hline $\begin{array}{l}\text { Klasa 1: } \\
\text { najwyższy poziom rozwoju } \\
\text { i obiektywnej jakości życia }\end{array}$ & brak & choszczeński, wałecki \\
\hline $\begin{array}{l}\text { Klasa 2: } \\
\text { średni poziom rozwoju } \\
\text { i obiektywnej jakości życia }\end{array}$ & $\begin{array}{l}\text { białogardzki, choszczeński, } \\
\text { drawski, goleniowski, gryficki, } \\
\text { kołobrzeski, koszaliński, } \\
\text { łobeski, myśliborski, sławieński, } \\
\text { stargardzki, szczecinecki, } \\
\text { świdwiński, wałecki }\end{array}$ & $\begin{array}{l}\text { drawski, goleniowski, gryficki, } \\
\text { kołobrzeski, koszaliński, } \\
\text { łobeski, myśliborski, sławieński, } \\
\text { stargardzki, szczecinecki, } \\
\text { świdwiński }\end{array}$ \\
\hline $\begin{array}{l}\text { Klasa 3: } \\
\text { niski poziom rozwoju } \\
\text { i obiektywnej jakości życia }\end{array}$ & m. Koszalin, m. Świnoujście & $\begin{array}{c}\text { białogardzki, gryfiński, } \\
\text { m. Koszalin, m. Swinoujście }\end{array}$ \\
\hline $\begin{array}{l}\text { Klasa 4: } \\
\text { najniższy poziom rozwo- } \\
\text { ju i obiektywnej jakości } \\
\text { życia }\end{array}$ & gryfiński, policki, m. Szczecin & m. Szczecin, policki \\
\hline
\end{tabular}

Analizując klasyfikację powiatów województwa zachodniopomorskiego, można zauważyć, że w 2007 roku ani jeden powiat nie należał do 1. klasy, czyli w żadnym nie było bardzo dobrych warunków środowiskowych jakości życia. Do klasy 2. należało 14 badanych powiatów (74\% ogółu) mających dobre warunki środowiskowe, tj. białogardzki, choszczeński, drawski, goleniowski, gryficki, kołobrzeski, koszaliński, łobeski, myśliborski, sławieński, stargardzki, szczecinecki, świdwiński, wałecki. Dwa powiaty (10\%) należały do klasy 3. o dostatecznych/przeciętnych warunkach środowiskowych (m. Koszalin, m. Świnoujście) i trzy powiaty (16\%) do klasy 4. o najgorszych uwarunkowaniach (gryfiński, policki, m. Szczecin). Podsumowując, w większości powiatów województwa zachodniopomorskiego były dobre środowiskowe uwarunkowania jakości życia, a w 26\% powiatów wymagają one poprawy.

W 2012 roku nastąpiły zmiany w klasyfikacji powiatów. Do klasy 1. awansowały dwa powiaty - choszczeński i wałecki z powodów, które przedstawiono, opisując zmiany w rankingu powiatów. W klasie 2. pozostało 11 powiatów (58\% ogółu badanych), tj. drawski, łobeski, sławieński, koszaliński, stargardzki, szczecinecki, 
świdwiński, myśliborski, goleniowski, gryficki, kołobrzeski. Natomiast w klasie 3., obok dotychczas do niej należących powiatów, tj. m. Koszalina i m. Świnoujścia, znalazły się powiat białogardzki, który był w klasie 2 . oraz powiat gryfiński, będący wcześniej w klasie 4 . Łącznie w 3 . klasie było $21 \%$ badanych powiatów.

Awans powiatu gryfińskiego wynikał z ograniczenia ilości odpadów wytwarzanych w ciągu roku na $1 \mathrm{~km}^{2}$ o ponad $35 \%$ (ich poziom prawie się zrównał ze średnim poziomem tego wskaźnika dla województwa), ograniczenia zanieczyszczeń pyłowych [w tonach/rok $/ 100 \mathrm{~km}^{2}$ ] o około $87 \%$ i zanieczyszczeń gazowych o około 13\% (zmiana ta była większa o 13 razy od średniego przyrostu dla województwa, który wynosił $1 \%$ ). Z kolei zdeklasowanie powiatu białogardzkiego wynikało z relatywnie dużego przyrostu ilości odpadów wytwarzanych w ciągu roku na $1 \mathrm{~km}^{2}$ o około 189\% i zwiększenia emisji zanieczyszczeń gazowych o około $61 \%$.

W klasie 4. pozostały tylko dwa powiaty $-\mathrm{m}$. Szczecin i policki, ale nawet one dokonały pozytywnych zmian w zakresie ochrony środowiska, mniej je obciążając, o czym wspomniano, omawiając ranking. Jednak te zmiany - przy dużym skumulowaniu i synergii zanieczyszczeń - były za małe, by przejść do wyższej klasy w tym zakresie.

Reasumując, w 2012 roku łącznie w 68\% powiatów były dobre warunki środowiskowe jakości życia, a w 32\% wymagające poprawy. Zatem w ciągu pięciu lat o 6\% zmniejszyła się liczba powiatów o dobrych uwarunkowaniach środowiskowych, zaś o $6 \%$ zwiększyła tych o gorszych warunkach środowiskowych.

\section{Podsumowanie}

Podsumowując, można powiedzieć, że w województwie zachodniopomorskim większość powiatów cechowała się dobrymi uwarunkowaniami środowiskowymi jakości życia. Powiaty o niższym obiektywnym poziomie jakości życia w tym zakresie to jednostki, na których terenie działają duże przedsiębiorstwa przemysłowe silnie oddziałujące na środowisko. Przedsiębiorstwa te prowadzą działalność proekologiczną, czego efektem było ograniczenie emisji różnych zanieczyszczeń, ale ich funkcjonowanie zawsze będzie stanowiło pewne obciążenie dla środowiska. Kwestią istotną jest zatem dostosowanie rodzaju i rozmiarów działalności gospodarczej oraz działań proochronnych do akceptowalnego społecznie poziomu zanieczyszczeń, tak by jakość życia nie uległa pogorszeniu. Należy bowiem pamiętać 
o dychotomicznym charakterze uwarunkowań środowiskowych - czystsze środowisko oddziałuje pozytywnie na warunki zdrowotne życia, pracy i odpoczynku, czyli jakość życia w tym obszarze, ale nie zawsze koreluje z wysokim poziomem rozwoju gospodarczego, tym bardziej, gdy region ma specyficzny charakter.

Dobre uwarunkowania środowiskowe powinno się jednak jak najszybciej wykorzystać do rozwoju społeczno-gospodarczego województwa. Taki kierunek wskazuje również Strategia Rozwoju Województwa Zachodniopomorskiego do roku 2020. W dokumencie tym do mocnych stron - nawiązujących do uwarunkowań środowiskowych - zaliczono m.in.:

- korzystną strukturę agrarną,

- bogate zasoby turystyczne,

- posiadanie walorów uzdrowiskowych i największych uzdrowisk nadmorskich w kraju,

- dobre warunki do uprawiania turystyki aktywnej i specjalistycznej,

- silnie rozwiniętą bazę noclegową w pasie nadmorskim,

- dużą liczbę gospodarstw produkujących żywność ekologiczną.

Natomiast do słabych stron w tym zakresie można zaliczyć:

- niedostatecznie wypromowane regionalne produkty turystyczne,

- niedostatecznie zbudowaną sieć informacji turystycznej w regionie,

- małą liczbę obiektów noclegowych o wysokim standardzie,

- niewielką i malejącą liczbę zakładów przetwórstwa spożywczego,

- dysproporcje efektywności pomiędzy sektorami gospodarki w regionie.

Biorąc powyższe pod uwagę, należy zintensyfikować działania, które zamienią słabości na atuty i uczynią z uwarunkowań środowiskowych dźwignię rozwoju społeczno-gospodarczego.

\section{Literatura}

Borys T., Jakość życia jako integrujący rodzaj jakości, w: Jakość życia w perspektywie nauk humanistycznych, ekonomicznych i ekologii, Akademia Ekonomiczna we Wrocławiu, Jelenia Góra 2003.

Dane Banku Danych Lokalnych, GUS 2014, www. stat.gov.pl (dostęp 20.04.2014).

Hellwig Z., Taksonometria ekonomiczna, jej osiagnięcia, zadania i cele, w: Taksonomia - teoria i jej zastosowania, red. J. Pociecha, Akademia Ekonomiczna w Krakowie, Kraków 1990. 
Jajuga K., Walesiak M., Taxonomic Conferences - Some Facts and Remarks, w: Taksonomia 14. Klasyfikacja $i$ analiza danych - teoria i zastosowania, Prace Naukowe Akademii Ekonomicznej im. Oskara Langego we Wrocławiu, Wrocław 2007.

Karmowska G., Krawczyk M., Kryk B., Maniak G., Marciniak M., Czynniki podnoszenia jakości życia $i$ dostępności do ustug publicznych na obszarze województwa zachodniopomorskiego, Raport dla Urzędu Marszałkowskiego WZP, Szczecin 2014.

Kukuła K., Elementy statystyki w zadaniach, Wydawnictwo Naukowe PWN, Warszawa 2010.

Strategia Rozwoju Województwa Zachodniopomorskiego do roku 2020, Urząd Marszałkowski Województwa Zachodniopomorskiego, Szczecin 2010.

Taksonomiczna analiza przestrzennego zróżnicowania poziomu życia $w$ Polsce $w$ ujęciu dynamicznym, red. A. Zeliaś, Wydawnictwo Akademii Ekonomicznej w Krakowie, Kraków 2000.

\title{
ENVIRONMENTAL DETERMINANTS OF LIVING QUALITY IN COUNTIES LOCATED IN WEST POMERANIAN VOIVODESHIP
}

\begin{abstract}
Since time important factor of living quality are the environmental determinants. In order to accomplish the aim of the paper, the author refers to the results of research on objective living quality conducted in counties located in West Pomeranian voivodeship and point out to strong and weakness for environmental determinants. Furthermore, the author discusses factors that have contributed to such results using desk research and taxonomic analysis.
\end{abstract}

Translated by Barbara Kryk

Keywords: living quality, region, environmental determinants

JEL codes: I3, R1 